\title{
Renal Cell Carcinoma Associated with Xp11.2 Translocation/TFE3 Gene Fusion: A Case Report with Immunohistochemical and Cytological Features
}

\author{
Takuji Tanaka1 ${ }^{*}$, Kuniaki Hirai ${ }^{2}$, Fumimasa Etori', Masashi Matsuyama ${ }^{1}$, \\ Naoki Watanabe1, Hiromi Kondo3 ${ }^{3}$ Masayoshi Tamaki ${ }^{3}$, Tatsuya Yamashita4, \\ Shiho Yasue ${ }^{4}$, Mika Noda ${ }^{4}$, Kunihiro Shinoda ${ }^{4}$, Hisao Komeda ${ }^{3}$ \\ ${ }^{1}$ Department of Diagnostic Pathology (DDP) \& Research Center of Diagnostic Pathology (RC-DiP), Gifu \\ Municipal Hospital, Gifu, Japan \\ ${ }^{2}$ Department of Radiology, Ehime University Graduate School of Medicine, Ehime, Japan \\ ${ }^{3}$ Department of Urology, Gifu Municipal Hospital, Gifu, Japan \\ ${ }^{4}$ Department of Pediatrics, Gifu Municipal Hospital, Gifu, Japan \\ Email: *takutt@toukaisaibou.co.jp
}

Received 28 December 2015; accepted 18 January 2016; published 22 January 2016

Copyright (C) 2016 by authors and Scientific Research Publishing Inc.

This work is licensed under the Creative Commons Attribution International License (CC BY). http://creativecommons.org/licenses/by/4.0/

(c) (†) Open Access

\begin{abstract}
Gene fusions involving two of the MiT subfamily factors, such as TFE3, TFEB, TFC and MiTF, have been identified in renal cell carcinoma (RCC). Xp11.2 translocation RCC is a rare pediatric neoplasm that harbors gene fusions involving TFE3, which plays an important role in cell proliferation and survival. We herein present a case of RCC associated with Xp11.2 translocation/TFE3 gene fusion in a 14-year-old Japanese boy presenting gross hematuria and body weight loss. The tumor was characterized by histopathology, cytology and TFE3-immunohistochemistry/immunocytochemistry. Knowledge of distinctive morphological and immunostaining features of this tumor can help to accurately diagnose this rare subset of translocation associated RCC in routine pathological diagnostic procedures.
\end{abstract}

\section{Keywords}

Renal Cell Carcinoma, Xp11.2 Translocation, TFE3, Cytology, Immunohistochemistry, Immunocytochemistry

\footnotetext{
${ }^{*}$ Corresponding author.
}

How to cite this paper: Tanaka, T., et al. (2016) Renal Cell Carcinoma Associated with Xp11.2 Translocation/TFE3 Gene Fusion: A Case Report with Immunohistochemical and Cytological Features. Open Journal of Pathology, 5, 19-25. 


\section{Introduction}

Gene fusions involving two of the MiT subfamily factors [1], such as transcription factor E3 (TFE3), transcription factor EB (TFEB), TFC and MiTF, have been identified in renal cell carcinoma (RCC) [2] [3]. An extremely rare RCC associated with Xp11.2 translocations and TFE3 fusions (Xp11.2 RCC) was recognized as a distinct entity in the WHO classification of kidney tumors in 2004 [4]. The first pediatric case of this distinct tumor was reported by Tomlinson et al. [5]. This RCC subtype is defined by different translocations involving chromosome Xp11.2, all of which result in TFE3 gene fusions. Fusions of the TFE3 gene with different genes includes ASPL(17q25), PRCC(1q21), PSF(1q34), NonO(Xq12) and CLTC(17q23) [6] [7]. PRCC-TFE3 RCCs [8] and ASPL-TFE3 RCCs [9] are the most frequent types of Xp11.2 translocation RCCs. The incidence of Xp11.2 translocation RCC is low: one-third of pediatric RCCs are estimated to be Xp11.2 translocation RCCs associated with TFE3 gene fusion [10], 0.9\% in adult RCCs [11], 15\% in young adult RCCs [12], and 54\% in child RCCs [3]. Another subset of RCC is associated with TFEB resulting from $\mathrm{t}(6 ; 11)$ (p21; q12).

For an accurate diagnosis, identification of the nuclear over expression of TFE3 protein by immunohistochemistry [13] is needed. We herein present a case report of this rare malignancy which was developed in a 14year-old Japanese boy, highlighting its histopathological, immunohistochemical and immunocytochemical features [6] [13] [14].

\section{Case Report}

Patient: A 14-year-old Japanese boy presented at our hospital with complaints of acuteabdominal pain (right side) and macrohematuria. He also complained of a fever. Because he noticed a $10 \mathrm{~kg}$ body weight loss over the previous year, the patient and his family wanted further examinations. No history of trauma or any other significant past history was reported. At admission, complete blood counts except for the white blood cell count (12, $210 / \mu \mathrm{L}$ ) were within normal limits. A blood biochemistry analysis showed elevated abnormalities in C-reactive protein (CRP, $2.23 \mathrm{mg} / \mathrm{dL}$ ) and neuron-specific enolase (NSE, $51.5 \mathrm{ng} / \mathrm{mL}$ ) levels. A urinalysis reported protein $\left(3^{+}\right)$and occult blood in the urine $\left(3^{+}\right)$. Abdominal computed tomography (CT, Figure 1), abdominal magnetic resonance imaging (MRI, Figure 2(A)) and a positron emission tomography (PET)-CT scan (Figure 2(B)) showed a large mass lesion $(78 \times 73 \times 112 \mathrm{~mm})$ with calcification in the right kidney, compressing the vena cava inferior and metastasis to the renal hilar lymph nodes (Figure 1 and Figure 2(B)). A bone scintigram revealed no distant metastases.

Pathology: Right radical nephrectomy was performed according to the clinical diagnosis of RCC or Wilms' tumor. A frozen section diagnosis during the operation reported papillary RCC. However, cytology of imprint touch smears from the cut surface of the tumor led us to suspect Xp11.2 translocation RCC, because epithelial cancer cells showing a positive reaction for TFE3 in the nuclei of neoplastic cells (Figure 3) proliferated with a papillary pattern. The removed kidney grossly had yellowish multi-nodular tumors with partly hemorrhagic and small cysts; the largest nodular tumor measured $7.2 \times 7.2 \times 6.8 \mathrm{~cm}$ in size (Figure 4). The tumor almost completely replaced the normal renal parenchyma. After a macroscopic examination, the removed tissue was fixed in $10 \%$ neutral buffered formalin and embedded in paraffin for the histopathological diagnosis. Histopathology revealed a biphasic population of neoplastic cells, large epithelioid cells with voluminous eosinophilic cytoplasm and severe nuclear atypia (Figure 5(A)) and smaller cells with clear cytoplasm and small round nuclei (Figure 5(B)). There were a few psammoma bodies. Necrotic areas were scattered throughout the tumor tissue. Invasion and infiltration of cancer cells into the fibrous capsule of the kidney and vessels (Figure 5(C)) were prominent. Immunohistochemistry showed strongly positive nuclear staining of TFE3 protein in the cancer cells (Figure 5(D)). Other immunohistochemical findings included negativity for cytokeratin (AE1/AE3) and SMA and focally positivity for CD10 and vimentin. Brown pigments in the cytoplasm were positive for HMB45. A RT-PCR analysis of an unfixed and fresh tumor sample showed SFPQ/PSF-TFE3 (+), ASPL-TFE3 (-) and PRCC-TFE3 (-). Five months after nephrectomy, metastases in the lymph nodes, bone and liver were found. Thereafter, the patient received anti-angiogenic tyrosine kinase inhibitor, pazopanib (Novartis Pharma K.K., Tokyo, Japan) [15], and a long-term intensive follow-up.

\section{Discussion}

Xp11.2 RCC is a rare malignancy that generally occurs in children and young adults [6]. This incidence is underestimated in adults because of its morphological similarities with clear cell and papillary RCCs. In addition, 

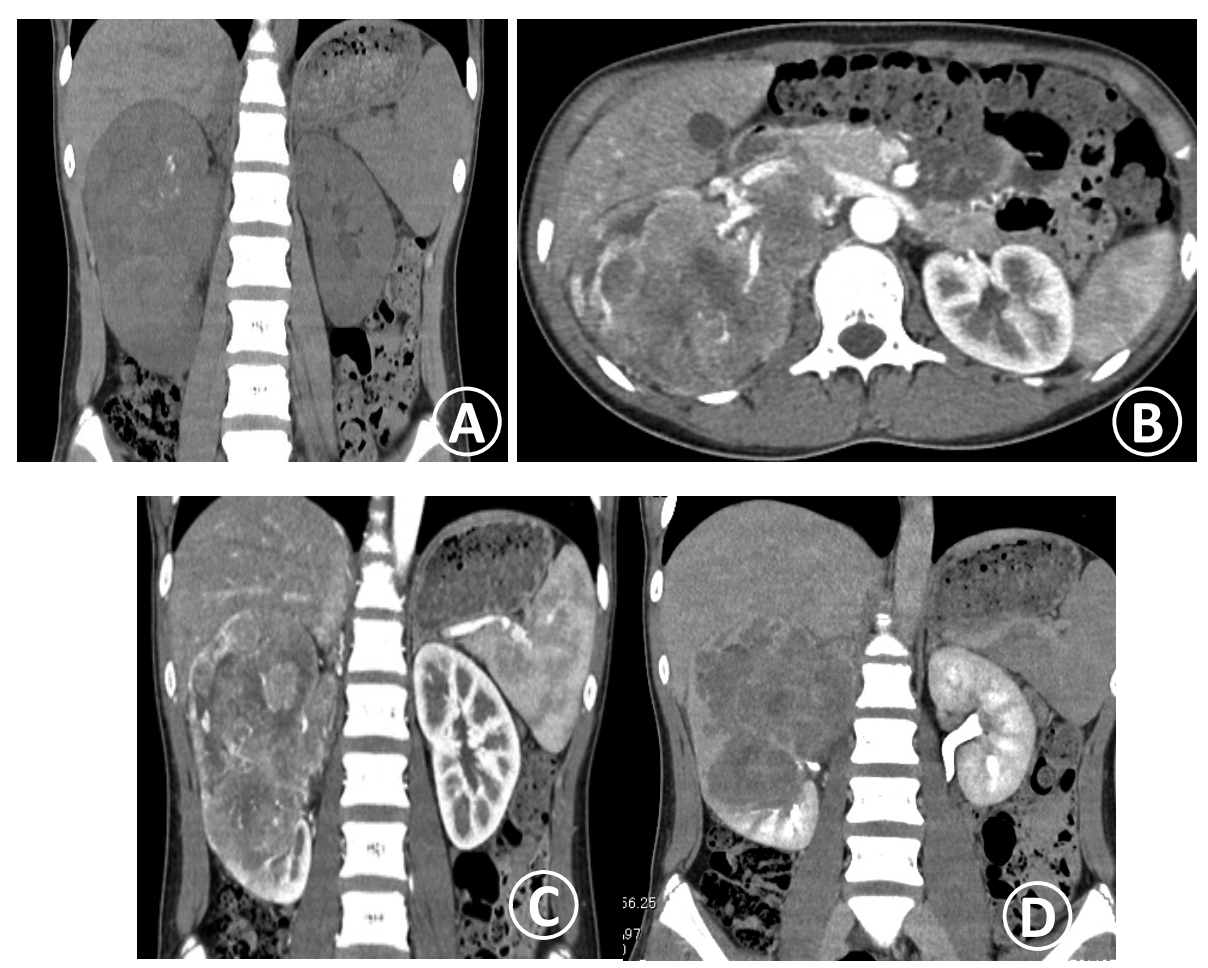

Figure 1. CT images of translocation RCC.CT scans of the abdomen and pelvis in the patient with (A) a coronal section showing a large right renal mass and an axial section (B) demonstrating heterogeneous and prolonged enhancement of the mass, measuring $7.8 \times 7.3 \times 11.2$ $\mathrm{cm}$ with microcystic areas and mottling calcification. Intravenous dynamic contrast-enhanced images (C) and (D) showing the delayed enhancement of the mass.
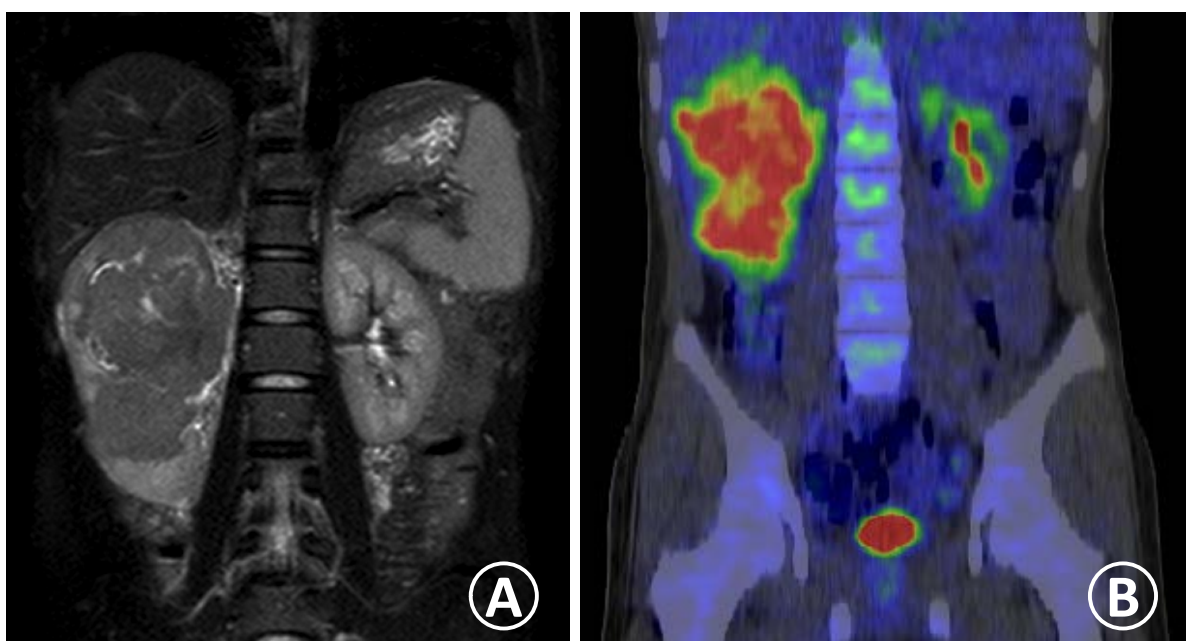

Figure 2. A coronal T2WI MRI image (A) showing an irregular ill-defined right renal mass with a heterogeneous and slightly high signal intensity. A PET-CT image (B) showing abnormal uptakes on FDG-PETin the right kidney and hilar lymph nodes

immunohistochemical and cytogenetic analyses are not carried out systematically in adults. The presence of the PSF-TFE3 fusion has only been described in a very limited number of cases [16]. We herein presented a novel case of SFPQ/PSF-TFE3-associated RCC in a 14-year-old Japanese boy.

The MiT subfamily of transcription factors includes TFE3, TFEB, TFC, and MiTF. Gene fusions involving two of these transcription factors were identified in RCC: Xp11.2 and $t(6 ; 11)$ translocation RCC [2]. Both 


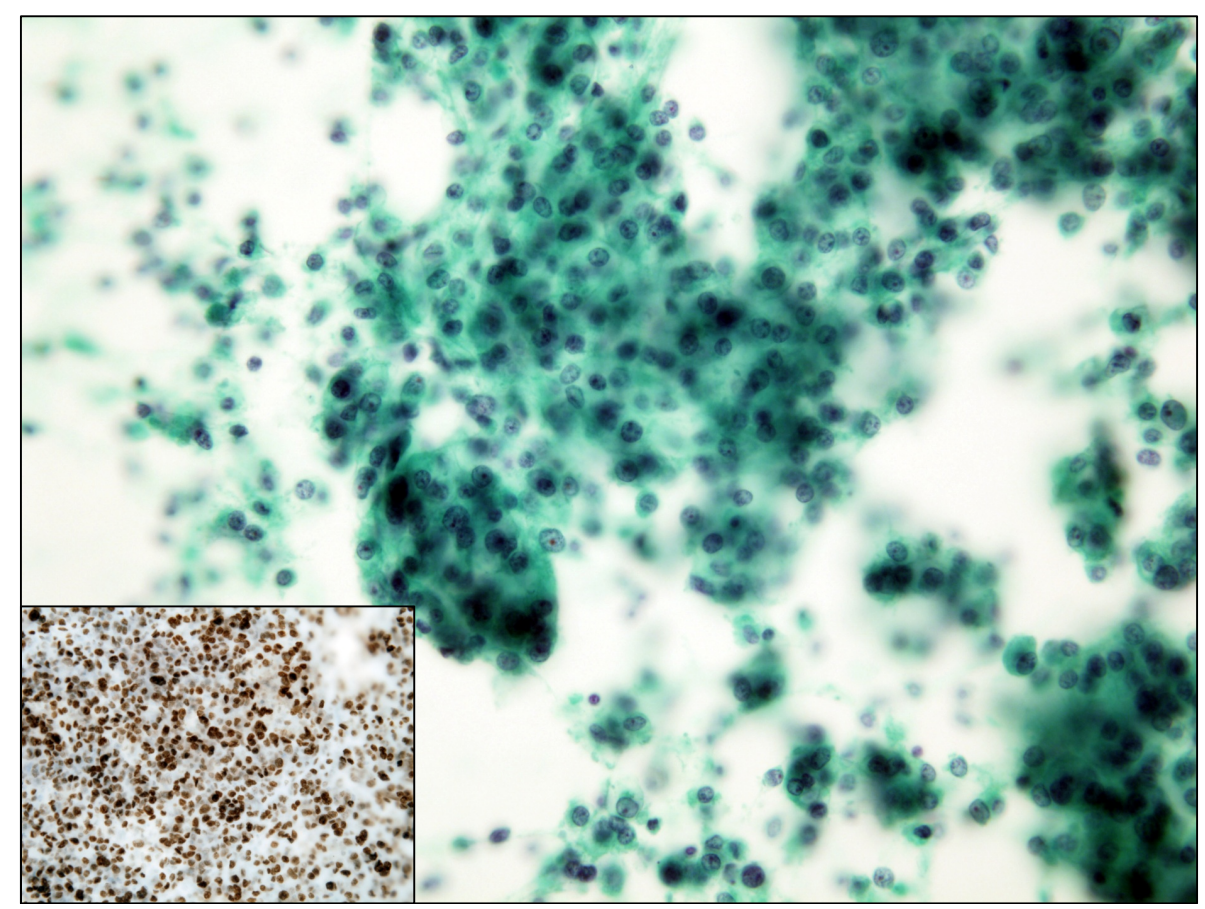

Figure 3. Imprint touch smear showing papillary clusters of cancer cells (Papanicolaou stain, $400 \times$ ). Note: strong nuclear positive reaction against TFE3 antibody (insert, TFE3 immunocytochemistry, 200×).

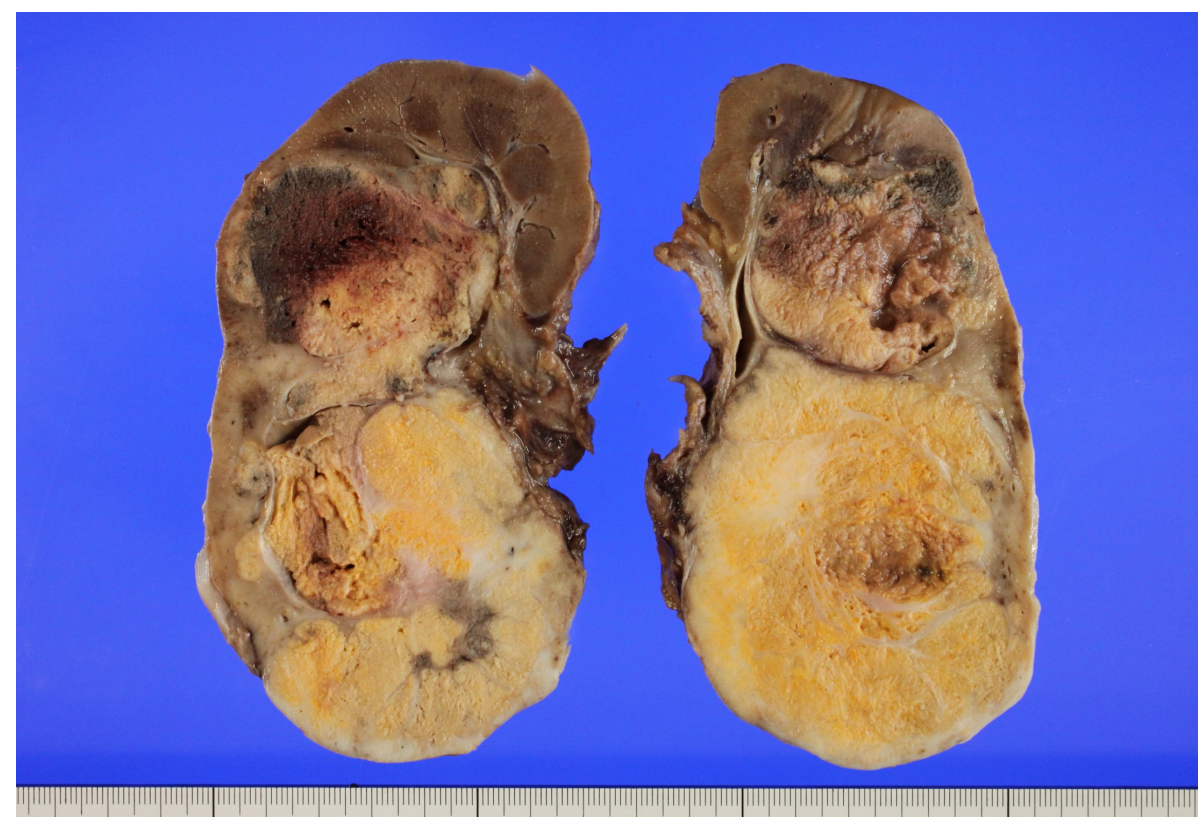

Figure 4. Cut surface showing yellowish multi-nodular tumors with partly hemorrhagic and small cysts. The tumor almost completely replaced the normal renal parenchyma.

neoplasms, grouped under the heading of "MiT family translocation RCC" [17], have a tendency toward young age at presentation. Specific immunohistochemistry analyses for nuclear proteins produced by both translocations are useful for an accurate diagnosis [13] [18]. Xp11 translocation RCC was first officially recognized in the 2004 WHO renal tumor classification [4], harboring gene fusions involving TFE3. The official recognition of the $\mathrm{t}(6 ; 11)$ RCC, harboring a specific alpha-TFEB gene fusion, was made in the 2013 International Society 


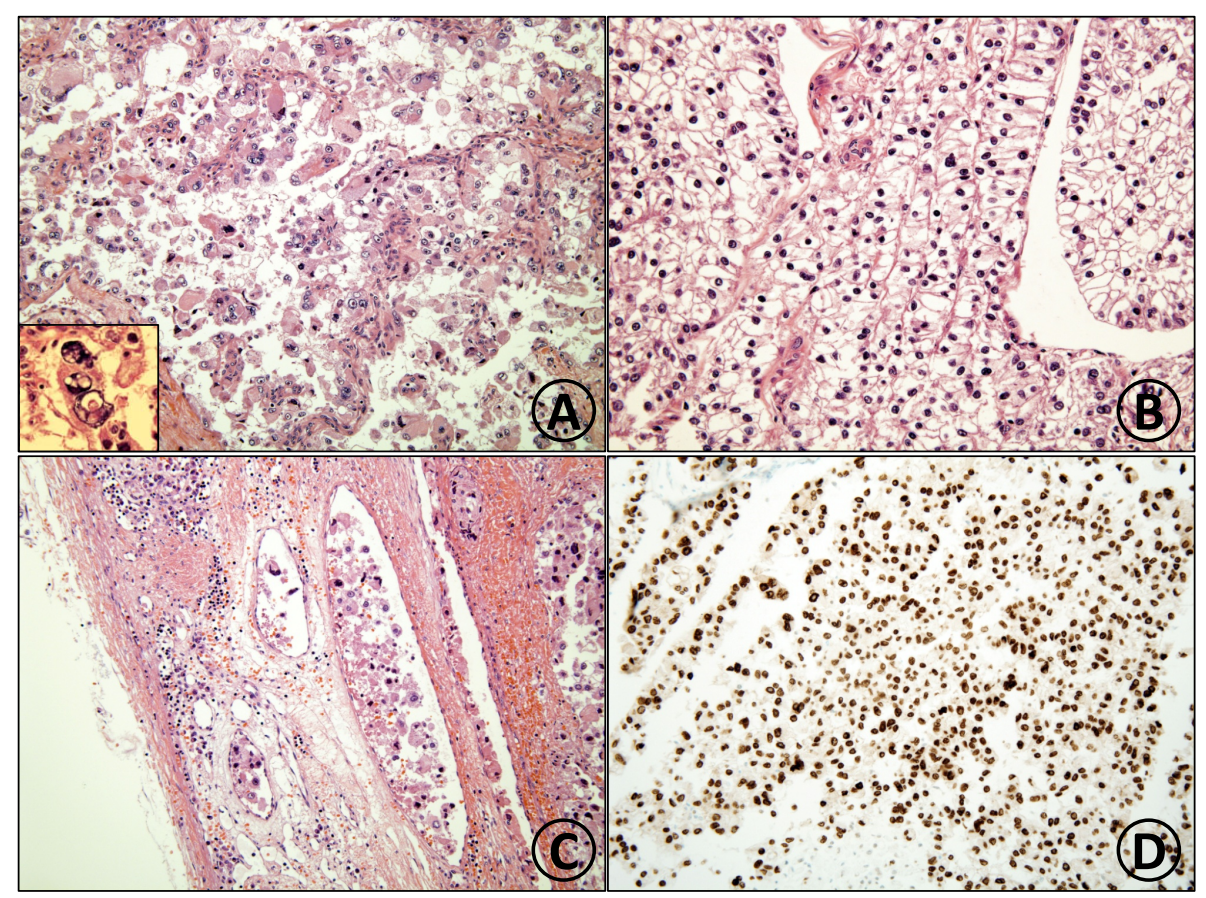

Figure 5. Histopathology of the resected right renal tumor. The tumor composed of (A) papillary growth of cancer cells with severe atypia and eosinophilic cytoplasm and (B) sheets of cancer cells with slight atypia and clear cytoplasm, the former predominating. (C) Cancer cells infiltrating into venous and lymphatic vessels. (D) A strong positive reaction against TFE3 antibody in the nuclei of cancer cells. Note: insert in (A), apsammoma body. (A)-(C); H \& E stain, 200×. (D) TFE3 immunohistochemistry, 200×. Insert, H \& E stain, 400×.

of Urologic Pathology (ISUP) Vancouver classification of renal neoplasia [17]. Histologically, the lesion is characterized by papillary architecture lined by clear and eosinophilic cells with abundant psammoma bodies [6] [18]. On the other hand, t(6;11) RCC has a biphasic appearance with both large and small epithelioid cells.

The morphology of these two neoplasms can overlap, thus the differential diagnosis is not simple. Histopathology of our case was similar to Xp11.2 translocation RCC, however, a few psammomatous bodies were observed on the tissue and smear samples. Immunohistochemistry of our case showed that the cancer cells were positive for TFE3 and HMB45, while negative for cytokeratin (AE1/AE3), SMA, CD10 and vimentin. The immunohistochemical marker for the diagnosis of Xp11.2 RCC is antibody against TFE3 protein [13] [19]. Immunocytochemistry also showed nuclear positivity of TFE3 in our case. Thus, the immunohistochemi$\mathrm{cal} /$ immuno- cytochemical marker for the diagnosis of Xp11.2 RCC is antibody against TFE3 protein [13] [19].

There are only a few reports on the cytological features of Xp11.2 RCC [14] [20]-[23]. Cytological samples included two fine needle aspirations, two touch imprint smears, and one voided/catheterized urine [14]. Kuwamoto et al. [14] strengthen the concept that the presence of sheets or clusters of cells with abundant clear or granular cytoplasm, round to oval nuclei, prominent nucleoli, occasional papillary clusters with fibrovascular/ hyalinized cores, and psammoma bodies in the background is characteristics of RCC associated with Xp11.2 translocations/TFE3 gene fusions. In our case, we noted a papillary pattern of atypical cell clusters with psammoma bodies on the touch imprint smears during operation. When considering the age of patient, we decided to perform TFE3-immunocytochemistry for the diagnosis of Xp11.2 RCC.

Xp11.2 RCC should be considered when a child or young adult patient presents with a renal tumor with heterogeneous features such as hemorrhaging, necrosis, cystic changes, and calcification on CT and MRI and/or is accompanied by metastatic evidence. A radiologic examination may be valuable for the diagnosis of Xp11.2 RCC [24], although only a few case reports focusing on its imaging features are available due to the rarity of Xp11.2 RCC. MRI is suggested to be superior to CT due to the increased soft-tissue contrast and multiple imaging weights of MRI, which better reveal the heterogeneous composition (such as hemorrhaging or necrosis) of this type of tumor [25]. However, the non-invasive diagnosis of this type of tumor is difficult, especially at the early stage. 
Treatments for Xp11.2 RCC include surgery, immunotherapy and molecular-targeted therapy. Surgical resection can achieve a favorable outcome for early stage Xp11.2 RCC. Recently, the assessment of the clinical efficacy of targeted agents, such as sunitinib (multikinase inhibitor), sorafenib (multikinase inhibitor) and everolimus (mTOR inhibitor), in patients with Xp11.2 RCC has been published [26]. At present, our patient is receiving treatment with an anti-angiogenic tyrosine kinase inhibitor, pazopanib, for metastatic tumors in the liver and bone. Xp11.2 RCC tends to develop in young patients with lymphnode metastasis. Further studies are needed to assess systemic therapy and the long-term prognosis.

In conclusion, when the patient's age and imaging findings are taken into account, the histopathological or cytological diagnosis may indicate this rare tumor as part of the differential diagnosis, and further investigations using immunohistochemistry and/or immunocytochemistry against TFE3 for accurate diagnosis are warranted.

\section{References}

[1] Hemesath, T.J., Steingrimsson, E., McGill, G., Hansen, M.J., Vaught, J., Hodgkinson, C.A., Arnheiter, H., Copeland, N.G., Jenkins, N.A. and Fisher, D.E. (1994) Microphthalmia, a Critical Factor in Melanocyte Development, Defines a Discrete Transcription Factor Family. Genes \& Development, 8, 2770-2780. http://dx.doi.org/10.1101/gad.8.22.2770

[2] Argani, P. (2015) MiT family Translocation Renal Cell Carcinoma. Seminars in Diagnostic Pathology, 32, $103-113$. http://dx.doi.org/10.1053/j.semdp.2015.02.003

[3] Ramphal, R., Pappo, A., Zielenska, M., Grant, R. and Ngan, B.Y. (2006) Pediatric Renal Cell Carcinoma: Clinical, Pathologic, and Molecular Abnormalities Associated with the Members of the MiT Transcription Factor Family. American Journal of Clinical Pathology, 126, 349-364. http://dx.doi.org/10.1309/98YE9E442AR7LX2X

[4] Argani, P. and Ladanyi, M. (2004) Renal Carcinomas Associated with Xp11. 2 Translocations/TFE3 Gene Fusions. In: Eble, J.N., Sauter, G., Epstein, J.I. and Sesterhenn, I.A., Eds., World Health Organization Classification of Tumours, IARC Press, Lyon, 37-38.

[5] Tomlinson, G.E., Nisen, P.D., Timmons, C.F. and Schneider, N.R. (1991) Cytogenetics of a Renal Cell Carcinoma in a 17-Month-Old Child. Evidence for Xp11.2 as a Recurring Breakpoint. Cancer Genetics and Cytogenetics, 57, 11-17. http://dx.doi.org/10.1016/0165-4608(91)90184-V

[6] Armah, H.B. and Parwani, A.V. (2010) Xp11.2 Translocation Renal Cell Carcinoma. Archives of Pathology \& Laboratory Medicine, 134, 124-129.

[7] Kuroda, N., Mikami, S., Pan, C.C., Cohen, R.J., Hes, O., Michal, M., Nagashima, Y., Tanaka, Y., Inoue, K., Shuin, T. and Lee, G.H. (2012) Review of Renal Carcinoma Associated with Xp11.2 Translocations/TFE3 Gene Fusions with Focus on Pathobiological Aspect. Histology and Histopathology, 27, 133-140.

[8] Argani, P., Antonescu, C.R., Couturier, J., Fournet, J.C., Sciot, R., Debiec-Rychter, M., Hutchinson, B., Reuter, V.E., Boccon-Gibod, L., Timmons, C., Hafez, N. and Ladanyi, M. (2002) PRCC-TFE3 Renal Carcinomas: Morphologic, Immunohistochemical, Ultrastructural, and Molecular Analysis of an Entity Associated with the t(X;1)(p11.2;q21). American Journal of Surgical Pathology, 26, 1553-1566. http://dx.doi.org/10.1097/00000478-200212000-00003

[9] Argani, P., Antonescu, C.R., Illei, P.B., Lui, M.Y., Timmons, C.F., Newbury, R., Reuter, V.E., Garvin, A.J., PerezAtayde, A.R., Fletcher, J.A., Beckwith, J.B., Bridge, J.A. and Ladanyi, M. (2001) Primary Renal Neoplasms with the ASPL-TFE3 Gene Fusion of Alveolar Soft Part Sarcoma: A Distinctive Tumor Entity Previously Included among Renal Cell Carcinomas of Children and Adolescents. The American Journal of Pathology, 159, 179-192. http://dx.doi.org/10.1016/S0002-9440(10)61684-7

[10] Argani, P. and Ladanyi, M. (2005) Translocation Carcinomas of the Kidney. Clinics in Laboratory Medicine, 25, 363378. http://dx.doi.org/10.1016/j.cll.2005.01.008

[11] Sukov, W.R., Hodge, J.C., Lohse, C.M., Leibovich, B.C., Thompson, R.H., Pearce, K.E., Wiktor, A.E. and Cheville, J.C. (2012) TFE3 Rearrangements in Adult Renal Cell Carcinoma: Clinical and Pathologic Features with Outcome in a Large Series of Consecutively Treated Patients. American Journal of Surgical Pathology, 36, 663-670. http://dx.doi.org/10.1097/pas.0b013e31824dd972

[12] Komai, Y., Fujiwara, M., Fujii, Y., Mukai, H., Yonese, J., Kawakami, S., Yamamoto, S., Migita, T., Ishikawa, Y., Kurata, M., Nakamura, T. and Fukui, I. (2009) Adult Xp11 Translocation Renal Cell Carcinoma Diagnosed by Cytogenetics and Immunohistochemistry. Clinical Cancer Research, 15, 1170-1176. http://dx.doi.org/10.1158/1078-0432.CCR-08-1183

[13] Truong, L.D. and Shen, S.S. (2011) Immunohistochemical Diagnosis of Renal Neoplasms. Archives of Pathology \& Laboratory Medicine, 135, 92-109.

[14] Kuwamoto, S., Murai, Y., Endo, Y., Masago, T., Kuroda, N. and Horie, Y. (2014) Cytologic Features of Renal Carcinoma Associated with Xp11.2 Translocations/TFE3 Gene Fusions: A Case Report with Voided and Catheterized Urine Cytology and a Literature Review. Acta Cytologica, 58, 406-412. http://dx.doi.org/10.1159/000366406 
[15] Bellmunt, J. and Dutcher, J. (2013) Targeted Therapies and the Treatment of Non-Clear Cell Renal Cell Carcinoma. Annals of Oncology, 24, 1730-1740. http://dx.doi.org/10.1093/annonc/mdt152

[16] Brassesco, M.S., Valera, E.T., Bonilha, T.A., Scrideli, C.A., Carvalho de Oliveira, J., Pezuk, J.A., Barros Silva, G.E., Costa, R.S. and Tone, L.G. (2011) Secondary PSF/TFE3-Associated Renal Cell Carcinoma in a Child Treated for Genitourinary Rhabdomyosarcoma. Cancer Genetics, 204, 108-110. http://dx.doi.org/10.1016/j.cancergencyto.2010.10.006

[17] Srigley, J.R., Delahunt, B., Eble, J.N., Egevad, L., Epstein, J.I., Grignon, D., Hes, O., Moch, H., Montironi, R., Tickoo, S.K., Zhou, M. and Argani, P. (2013) The International Society of Urological Pathology (ISUP) Vancouver Classification of Renal Neoplasia. American Journal of Surgical Pathology, 37, 1469-1489. http://dx.doi.org/10.1097/PAS.0b013e318299f2d1

[18] Kryvenko, O.N., Jorda, M., Argani, P. and Epstein, J.I. (2014) Diagnostic Approach to Eosinophilic Renal Neoplasms. Archives of Pathology \& Laboratory Medicin, 138, 1531-1541. http://dx.doi.org/10.5858/arpa.2013-0653-RA

[19] Argani, P., Lal, P., Hutchinson, B., Lui, M.Y., Reuter, V.E. and Ladanyi, M. (2003) Aberrant Nuclear Immunoreactivity for TFE3 in Neoplasms with TFE3 Gene Fusions: A Sensitive and Specific Immunohistochemical Assay. American Journal of Surgical Pathology, 27, 750-761. http://dx.doi.org/10.1097/00000478-200306000-00005

[20] Barroca, H., Correia, C. and Castedo, S. (2008) Cytologic and Cytogenetic Diagnosis of Pediatric Renal Cell Carcinoma Associated with t(X;17). Acta Cytologica, 52, 384-386. http://dx.doi.org/10.1159/000325531

[21] Mansouri, D., Dimet, S., Couanet, D., Terrier-Lacombe, M.J., Vasiliu, V., Khalifa, C., Suciu, V. and Vielh, P. (2006) Renal Cell Carcinoma with an Xp11.2 Translocation in a 16-Year-Old Girl: A Case Report with Cytological Features. Diagnostic Cytopathology, 34, 757-760. http://dx.doi.org/10.1002/dc.20523

[22] Schinstine, M., Filie, A.C., Torres-Cabala, C., Abati, A., Linehan, W.M. and Merino, M. (2006) Fine-Needle Aspiration of a Xp11.2 Translocation/TFE3 Fusion Renal Cell Carcinoma Metastatic to the Lung: Report of a Case and Review of the Literature. Diagnostic Cytopathology, 34, 751-756. http://dx.doi.org/10.1002/dc.20548

[23] Yamaguchi, T., Kuroda, N., Imamura, Y., Hes, O., Kawada, T. and Nakayama, K. (2009) Imprint Cytologic Features in Renal Cell Carcinoma Associated with Xp11.2 Translocation/TFE3 Gene Fusion in an Adult: A Case Report. Acta Cytologica, 53, 693-697. http://dx.doi.org/10.1159/000325412

[24] Kato, H., Kanematsu, M., Yokoi, S., Miwa, K., Horie, K., Deguchi, T. and Hirose, Y. (2011) Renal Cell Carcinoma Associated with Xp11.2 Translocation/TFE3 Gene Fusion: Radiological Findings Mimicking Papillary Subtype. Journal of Magnetic Resonance Imaging, 33, 217-220. http://dx.doi.org/10.1002/jmri.22392

[25] Kondo, T., Nakazawa, H., Sakai, F., Kuwata, T., Onitsuka, S., Hashimoto, Y. and Toma, H. (2004) Spoke-Wheel-Like Enhancement as an Important Imaging Finding of Chromophobe Cell Renal Carcinoma: A Retrospective Analysis on Computed Tomography and Magnetic Resonance Imaging Studies. International Journal of Urology, 11, 817-824. http://dx.doi.org/10.1111/j.1442-2042.2004.00907.x

[26] Malouf, G.G., Camparo, P., Oudard, S., Schleiermacher, G., Theodore, C., Rustine, A., Dutcher, J., Billemont, B., Rixe, O., Bompas, E., Guillot, A., Boccon-Gibod, L., Couturier, J., Molinie, V. and Escudier, B. (2010) Targeted Agents in Metastatic Xp11 Translocation/TFE3 Gene Fusion Renal Cell Carcinoma (RCC): A Report from the Juvenile RCC Network. Annals of Oncology, 21, 1834-1838. http://dx.doi.org/10.1093/annonc/mdq029 